\title{
Assessment of groundwater quality for drinking and irrigation purpose using hydrochemical studies in Dera Bassi town and its surrounding agricultural area of Dera Bassi Tehsil of Punjab, India
}

\author{
Nitish Sharma ${ }^{1}$. Upma Vaid ${ }^{1}$ · Sanjay Kumar Sharma ${ }^{2}$ \\ Received: 25 August 2020 / Accepted: 12 January 2021 / Published online: 1 February 2021 \\ (c) The Author(s) $2021 \quad$ OPEN
}

\begin{abstract}
Present research aims to assess the suitability of groundwater of Dera Bassi town (Punjab) and its surrounding agricultural area for drinking as well as irrigation purpose. Thirty groundwater samples were collected (in February 2020) and analyzed for various physicochemical parameters. Results of physicochemical analysis were compared with Indian (IS 10500:2012) as well as WHO (2006) standards to ascertain the suitability of the groundwater samples for drinking purpose, and it has been found that results for almost all the parameters except alkalinity (at few sites) are within the permissible limit. The pattern of ionic dominance was observed in the order of $\mathrm{Ca}^{2+}>\mathrm{Mg}^{2+}>\mathrm{Na}^{+}>\mathrm{K}^{+}$for cations and $\mathrm{Cl}^{-}>\mathrm{NO}_{3}{ }^{-}>\mathrm{SO}_{4}{ }^{2-}>\mathrm{F}^{-}$for anions. Further, according to the observed Kelly's ratio, sodium adsorption ratio, sodium percentage, corrosivity ratio and permeability index, the groundwater samples were found to be fit for irrigation purpose. However, the magnesium ratio and residual sodium carbonate revealed that groundwater of the area under study is not fit for irrigation purpose at some sites. The plot of SAR values versus EC values in the US Salinity Laboratory diagram revealed that the majority of the samples fall under water type C3-S1 (high salinity-low SAR) and 36.77\% samples fall under water type C2-S1 (medium salinity-low SAR). Gibb's diagram revealed that all samples fall under rock dominance category. The values of index of base exchange (CAI 1 and CAI 2) indicate that both direct ion and reverse ion exchange processes are taking place in the region.
\end{abstract}

Keywords Groundwater - Dera Bassi · Drinking and irrigation water quality · Chadha's plot · Permeability index · Index of base exchange

\section{Introduction}

Distribution of freshwater resources is not uniform across the globe, and with the increasing population the surface water resources seem to be inadequate in many parts of the world. Hence, groundwater is now being exploited as a major source to meet water demand for drinking and irrigation [1-3]. Nowadays, approximately one third population of the world rely on groundwater resources to meet their drinking water requirement $[3,4]$. Though, groundwater contamination due to natural environmental changes and anthropogenic activities like agricultural and industrial activities is also getting degraded which is leading to water shortage crisis in many parts of the world [5, $6]$.

The scenario is more critical in India as the country ranks second in the world as per population and it is difficult to meet the drinking water demands of such a huge population. Hence, due to consumption of contaminated water, many people die every year in India [7]. The groundwater is considered as clean and safe for the drinking purposes in comparison with surface water

Upma Vaid, upmavaid@gmail.com; Nitish Sharma, ntsharma39@gmail.com; Sanjay Kumar Sharma, sanjay.nihr@gov.in |'Chandigarh University, Gharuan, Mohali, Punjab, India. ${ }^{2}$ National Institute of Hydrology, Guwahati, India. 
because when it percolates through ground, majority of the pollutants get degraded [8]. Thus, in the last few decades groundwater has become an important commodity in India. In fact, India is now among the highest users of groundwater and total consumption per year is approximately 230 cubic kilometers of groundwater. However, excessive use of groundwater resources may affect the quality and quantity of the groundwater. India has more than 30 million groundwater extraction points and in the majority of these wells, water level decline was observed in pre-monsoon months from 2006 to 2015 [9]. Moreover, as it is well known that water is a universal solvent and has the ability to dissolve all substances that comes in its contact [10]. Hence, the groundwater quality gets affected by geochemical compositions of the rocks, as well as human activities [1]. Some minerals entering into groundwater are although important for the human beings and animals, but their higher concentration may also cause toxic effects [10].

Punjab is known as the "Granary of India" where different varieties of crops are grown. It is situated near to the Himalayas. In 1990, the modern agriculture model adopted by the state increased the crop productivity significantly with an application of chemical fertilizers, pesticides and intensive irrigation. The Punjab state is one of the highest consumers of fertilizers $(243 \mathrm{~kg} / \mathrm{hec}-$ tare per year) and pesticides [11, 12]. These fertilizers and pesticides enter in groundwater and surface water primarily through agricultural runoff. Although adopting these modern agriculture practices have played a vital role in achieving the maximum crop production but in the last few decades, intensive usage of agrochemicals has led to deterioration of surface as well as groundwater quality [13-15]. Agricultural modernization is not the only reason of deterioration of groundwater quality, but industrialization and urbanization are also contributing towards the degradation of water quality [16-20]. This deterioration of groundwater quality may cause a serious threat to the health of the people [21]. In Punjab, 90 cancer patients per 1 Lakh population have been reported and drinking of contaminated groundwater could be the one of the reasons [22].

Dera Bassi, Punjab, is an example where around 300 industries like Pharmaceuticals, Chemicals, Brick kilns, etc., are situated. The wastewater from some of these industries is flowing into a drain crossing between Dera Bassi and Bhankerpur. Even the groundwater of different villages and regions of Dera Bassi is deteriorating due to the effluent released from industries [23]. Therefore, in this study, the hydro-chemical parameters of groundwater were studied to check its suitability and safety for drinking and agricultural purpose.

\section{Materials and methods}

\subsection{Study area}

Dera Bassi is located in district SAS Nagar also known as Mohali. The district SAS Nagar is divided into three Tehsils, i.e. Dera Bassi, Mohali and Kharar. Dera Bassi Tehsil includes the total area of $389 \mathrm{~km}^{2}$ and its Dera Bassi town is spread over an area of $20 \mathrm{~km}^{2}$. Dera Bassi town is located on National Highway-152 on Chandigarh-Delhi Highway and near to Chandigarh, Mohali and Panchkula. It is an industrial town where various types of industries like pharmaceutical, chemicals, paper mills, brick kilns, electroplating, etc., are situated. The total area of the study region is $54 \mathrm{~km}^{2}$ which includes the Dera Bassi town and surrounding agricultural region with the coordinates $30.5887^{\circ} \mathrm{N}$ and $76.8471^{\circ} \mathrm{E}$. Dera Bassi is located near foothills of the Sivalik Himalayas in northwest India at an average altitude of 1053 feet. Dera Bassi has a humid subtropical climate (very hot in summers and mild in winters) with large variation in temperature $\left(-1{ }^{\circ} \mathrm{C}\right.$ to $\left.46^{\circ} \mathrm{C}\right)$. During monsoon, Dera Bassi receives moderate to heavy rainfall and sometimes heavy to very heavy rainfall. The study region receives normal monsoon rainfall of $619 \mathrm{~mm}$, non-monsoon rainfall of $152 \mathrm{~mm}$ and annual average rainfall of $771 \mathrm{~mm}$. The Ghaggar River flows at $5 \mathrm{~km}$ from the town of Dera Bassi. The region is occupied by quaternary alluvial sediments comprises of clay, silt, sand or the mixtures of all. The quaternary alluvial sediments are classified into two categories, i.e. newer alluvium and older alluvium. Quaternary alluvial sediments belong to the Indo-Gangetic alluvial plains, which form the main aquifer system. Groundwater present at the phreatic conditions in the shallow aquifer and leaky confined to confined conditions in the deeper aquifers. The groundwater resources are available in the study area at a varying depth of $11.73 \mathrm{~m}$ to $300 \mathrm{~m}$. Groundwater resources are overexploited in this area.

\subsection{Groundwater sampling and analysis}

Before the rainy season (February 2020), thirty groundwater samples were collected from various locations of Dera Bassi. The list of sampling sites is given in Table 1, and Fig. 1 shows the locations of different sampling in the study area. Groundwater samples were collected in high-grade polythene bottles of $1 \mathrm{~L}$ capacity after $5 \mathrm{~min}$ of pumping from bore wells/hand pumps. Samples were kept at $4{ }^{\circ} \mathrm{C}$ and taken to the laboratory for further chemical testing. Methods and procedures followed during 
Table 1 Sampling sites in Dera Bassi region of Punjab

\begin{tabular}{|c|c|c|c|c|}
\hline Sample & Sites & Latitude & Longitude & Source \\
\hline S1 & Preet Nagar & 30.585062 & 76.848621 & Borewell \\
\hline S2 & Bhagat Singh Nagar & 30.583014 & 76.850480 & Borewell \\
\hline S3 & Gauri Shankar Mandir & 30.583905 & 76.855376 & Borewell \\
\hline S4 & College colony & 30.578808 & 76.850320 & Borewell \\
\hline S5 & Shakti Nagar & 30.579303 & 76.844312 & Borewell \\
\hline S6 & Saraswati Vihar & 30.577796 & 76.836729 & Borewell \\
\hline S7 & Adarsh Nagar & 30.581802 & 76.840394 & Borewell \\
\hline S8 & Punjabi Nagar & 30.584001 & 76.837499 & Borewell \\
\hline S9 & Mohan Nagar & 30.583575 & 76.841783 & Borewell \\
\hline S10 & Anaj Mandi & 30.588529 & 76.842450 & Borewell \\
\hline S11 & Issapur Colony & 30.590014 & 76.836952 & Borewell \\
\hline $\mathrm{S} 12$ & Issapur Village & 30.592516 & 76.831030 & Borewell \\
\hline S13 & DeraJagadhri & 30.590374 & 76.826800 & Borewell \\
\hline S14 & Dhanauni & 30.580108 & 76.825351 & Borewell \\
\hline S15 & Rouni & 30.599903 & 76.837423 & Borewell \\
\hline S16 & Sai Enclave & 30.597728 & 76.848986 & Borewell \\
\hline S17 & Palm City & 30.602347 & 76.858976 & Borewell \\
\hline S18 & Said he Majra & 30.609384 & 76.854418 & Borewell \\
\hline S19 & Said he Majra & 30.606577 & 76.856435 & Hand pump \\
\hline S20 & Near Hansa tube pvt.Itd & 30.599235 & 76.859694 & Borewell \\
\hline S21 & Gurubaksh Colony & 30.589718 & 76.852363 & Borewell \\
\hline S22 & Shivpuri Colony & 30.590257 & 76.851136 & Borewell \\
\hline S23 & Gurudwara Tavaser Sahib & 30.594976 & 76.863835 & Borewell \\
\hline S24 & Angrish Shiv Mandir & 30.589556 & 76.847848 & Hand pump \\
\hline S25 & Near Kudos pvt. Ltd & 30.585010 & 76.8773178 & Borewell \\
\hline S26 & Angel Property, Bhankerpur & 30.605525 & 76.835004 & Borewell \\
\hline S27 & Bhankerpur Village & 30.604925 & 76.837933 & Borewell \\
\hline S28 & Bhankerpur Colony & 30.601862 & 76.837123 & Borewell \\
\hline S29 & Bhankerpur Colony & 30.601917 & 76.840336 & Borewell \\
\hline S30 & Issapur village near overhead tank & 30.594617 & 76.829313 & Borewell \\
\hline
\end{tabular}

the analysis of cations and anions were according to the APHA, 2017 [24]. Electrical conductivity was determined by the standard conductivity meter and the precision of the instrument ranges from 0.1 to $1 \%$. The total dissolved solids concentration was measured by using standard glass fiber filter method. Alkalinity, hardness, calcium ion and chloride were analyzed by titration method. Magnesium ion concentration was calculated from the formula using total hardness and calcium hardness. First of all, calcium hardness was determined by multiplying the calcium ion concentration with a factor of 2.5. Further, magnesium ion concentration was determined by multiplying the difference of total and calcium hardness with 0.243 . Fluoride and nitrate were analyzed by spectrophotometric technique. For the analysis of sulphate, a turbidimetric method was used and it works in the range of 1 to $40 \mathrm{mg} / \mathrm{L}$. Flame emission photometric method was used to calculate the sodium and potassium concentration in the groundwater.

\subsection{Evaluation of groundwater quality for irrigation purpose}

Groundwater is also used as irrigational water in the Dera Bassi region, so the irrigation water quality is required to evaluate. Hence, following parameters are considered to evaluate the suitability of groundwater for irrigation purpose:

\subsubsection{Sodium adsorption ratio (SAR)}

The sodium adsorption ratio (SAR) value is determined from the concentration of the main alkaline and earth alkaline cation available in the water. Richard [25] had given an equation to calculate the values of sodium adsorption ratio, which is given as: 


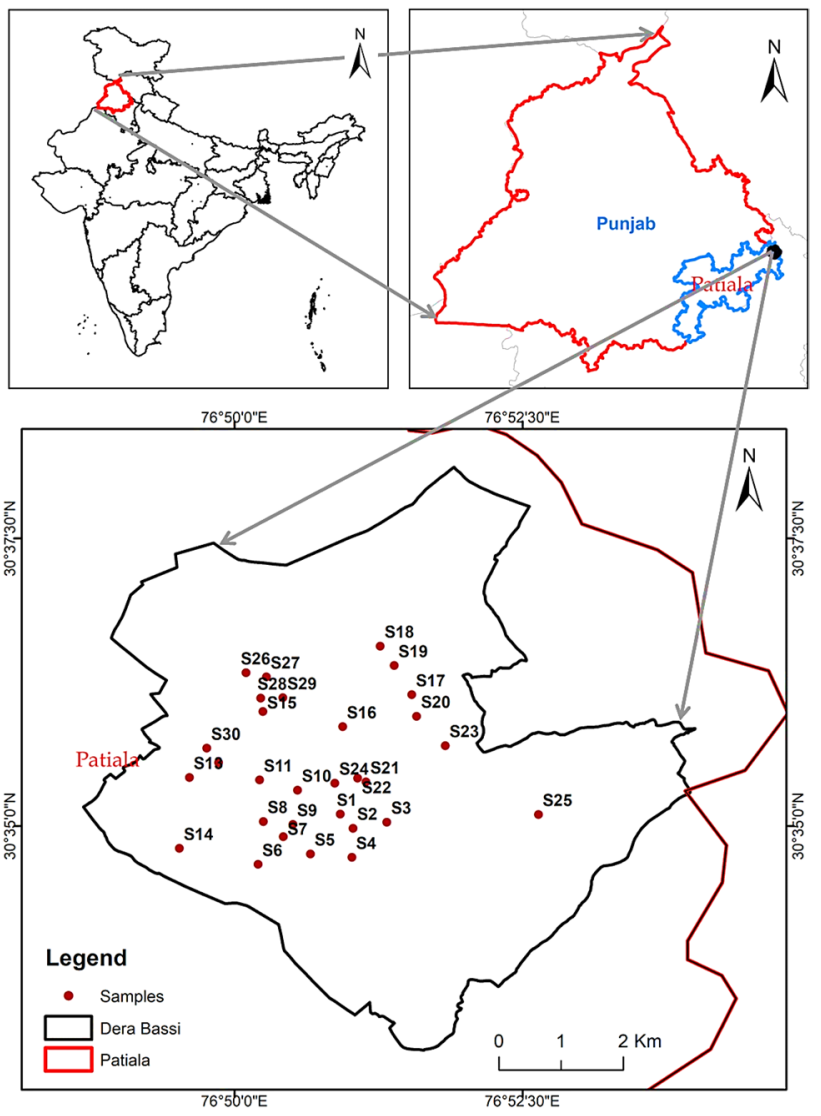

Fig. 1 Location of Dera Bassi, SAS district, Punjab

$\mathrm{SAR}=\frac{\mathrm{Na}^{+}}{\sqrt{\left(\mathrm{Ca}^{2+}+\mathrm{Mg}^{2+}\right) / 2}}$

Cation concentration is expressed in meq/L. If the concentration of sodium is high in irrigation water, then it may increase the soil sodium content and due to that permeability of soil may get affected which causes infiltration problems. The dispersion of soil may occur and the soil becomes hard to plough [26].

\subsubsection{Sodium percentage ( $\mathrm{Na} \%)$}

Wilcox [27] estimated the sodium percentage for classification of irrigation water as per Eq. (2).

$\% \mathrm{Na}=\frac{\left(\mathrm{Na}^{+}+\mathrm{K}^{+}\right) * 100}{\left(\mathrm{Ca}^{2+}+\mathrm{Mg}^{2+}+\mathrm{Na}^{+}+\mathrm{K}^{+}\right)}$

All the cations are expressed in meq/L. Higher percentage of sodium ion in irrigation water results in displacing the $\mathrm{Ca}^{2+}$ and $\mathrm{Mg}^{2+}$ from soil in exchange of $\mathrm{Na}^{+}$in water. When sodium reacts with the soil, permeability of soil gets affected and soil becomes very hard to plough which means that sodium concentration is important to evaluate to know the irrigation water quality.

\subsubsection{Kelly's ratio (KR)}

Kelly [28] had given an equation which is expressed as:

$\mathrm{KR}=\frac{\mathrm{Na}^{+}}{\mathrm{Ca}^{2+}+\mathrm{Mg}^{2+}}$

where cation concentration is given as meq/L. Kelly's ratio should be less than 1. If the value exceeds 1, groundwater is considered unfit for irrigation. High amount of sodium in irrigation water, then sodium ions are absorbed by clay particles replacing the calcium and magnesium ions which causes the dispersion of clay particles and diminishes the permeability of soil and can eventually affect the internal drainage.

\subsubsection{Magnesium ratio (MR)}

Szabolcs and Darabin [29] proposed an equation called as magnesium ratio which is expressed as:

$\mathrm{MR}=\frac{\mathrm{Mg}^{2+}}{\mathrm{Ca}^{2+}+\mathrm{Mg}^{2+}} * 100$

All cations should be in $\mathrm{meq} / \mathrm{L}$. Magnesium ratio in water should be more than $50 \%$ for irrigation purpose because high concentration of magnesium increases the soil alkalinity and affects the soil quality $[30,31]$.

\subsubsection{Corrosivity ratio (CR)}

Corrosivity ratio is expressed as:

$\mathrm{CR}=\frac{\frac{\mathrm{Cl}^{-}}{35.5}+2\left(\frac{\mathrm{SO}_{4}^{2-}}{96}\right)}{2\left(\frac{\mathrm{HCO}_{3}^{-}+\mathrm{CO}_{3}^{2-}}{100}\right)}$

All the anions should be in meq/L. Corrosivity ratio expresses whether the transportation of water through pipe is possible or not. CR value should be less than 1 for the transportation of groundwater through pipes. If the value exceeds 1 that specifies the corrosive nature of groundwater and in such case, noncorrosive pipes are required for uplifting and transportation of groundwater [32].

\subsubsection{Residual sodium carbonate (RSC)}

If higher percentage of $\mathrm{HCO}_{3}{ }^{-}$and $\mathrm{CO}_{3}{ }^{2-}$ is present in groundwater, then these may tend to form precipitates with $\mathrm{Ca}^{2+}$ and $\mathrm{Mg}^{2+}$ ions and excess amount of $\mathrm{NaHCO}_{3}$ and 
$\mathrm{CaCO}_{3}$ may be hazardous for the structure of soil. Eaton [33] had given an equation to calculate the RSC:

$\mathrm{RSC}=\left(\mathrm{HCO}^{3-}+\mathrm{CO}_{3}^{2-}\right)-\left(\mathrm{Ca}^{2+}+\mathrm{Mg}^{2+}\right)$

All the anions and cations are expressed in meq/L. As per Lloyd and Heathcote [34] classification, water with RSC value below 1.25 is suitable and up to 2.5 is marginally suitable for irrigation. But RSC value above 2.5 is considered as unsafe for the irrigation purpose.

\subsubsection{Permeability index}

Doneen [35] developed permeability index to estimate the fitness of water for irrigation uses.

$\mathrm{PI}=\frac{\mathrm{Na}^{+}+\sqrt{\mathrm{HCO}_{3}^{-}}}{\mathrm{Ca}^{2+}+\mathrm{Mg}^{2+}+\mathrm{Na}^{+}} * 100$

Groundwater water can be categorized into three classes on the basis of PI. The class I water shows $100 \%$ maximum permeability is suitable for irrigation. The class II water shows $75 \%$ maximum permeability and is marginally fit for irrigation, whereas the class III water having $25 \%$ maximum permeability is unsuitable for irrigation.

\section{Result and discussion}

Results of all the water quality parameters for the groundwater samples of the area under study are shown in Table 2.

\subsection{Groundwater quality assessment for drinking purpose}

Values of different parameters observed in present study are compared with the Indian standards (BIS 2012) [36] and WHO (2006) standards [37] as mentioned in Table 2.

It was observed that the $\mathrm{pH}$ values for all samples were within the permissible limits. The observed concentrations of EC were ranging from 583 to $1596 \mu \mathrm{S} / \mathrm{cm}$. Total dissolved solids (TDS) concentration in the groundwater samples varied from 337 to $937 \mathrm{mg} / \mathrm{L}$ with an avg. value of $555.7 \mathrm{mg} / \mathrm{L}$. It is evident from Fig. 2a that TDS concentration of sixteen samples was within desirable limits while for the rest of the 14 samples ( $\mathrm{S} 1, \mathrm{~S} 2, \mathrm{~S} 4, \mathrm{~S} 8, \mathrm{~S} 9, \mathrm{~S} 13$, $\mathrm{S} 15, \mathrm{~S} 20, \mathrm{~S} 22, \mathrm{~S} 23, \mathrm{~S} 26, \mathrm{~S} 27, \mathrm{~S} 28$ and S30) concentration was between desirable and permissible limits. None of the sample was having value greater than the permissible limits. TDS concentration more than $500 \mathrm{mg} / \mathrm{L}$ has been reported to affect the digestive system and hence, not considered to be safe for drinking purpose [36].

The bicarbonate alkalinity in the groundwater samples of the area under study was also analyzed. Bicarbonate is formed when two different sources of carbon dioxide, one is atmospheric and other is carbon dioxide,

Table 2 Summary of physico-chemical parameters of samples taken from different sites

\begin{tabular}{|c|c|c|c|c|c|c|c|c|c|}
\hline \multirow{2}{*}{$\begin{array}{l}\text { Water quality } \\
\text { parameters }\end{array}$} & \multicolumn{2}{|c|}{ BIS standards (10,500:2012) } & \multicolumn{2}{|c|}{ WHO (2006) } & \multicolumn{3}{|c|}{ Results } & \multirow{2}{*}{$\begin{array}{l}\text { Samples exceed- } \\
\text { ing desirable limit } \\
\text { of BIS }\end{array}$} & \multirow{2}{*}{$\begin{array}{l}\text { Samples exceeding } \\
\text { desirable limit of } \\
\text { WHO }\end{array}$} \\
\hline & $\begin{array}{l}\text { Max desirable } \\
\text { limit }\end{array}$ & $\begin{array}{l}\text { Max per- } \\
\text { missible } \\
\text { limit }\end{array}$ & $\begin{array}{l}\text { Max } \\
\text { desirable } \\
\text { limit }\end{array}$ & $\begin{array}{l}\text { Max per- } \\
\text { missible } \\
\text { limit }\end{array}$ & Min & Max & Avg & & \\
\hline $\mathrm{pH}^{*}$ & $6.5-8.5$ & - & 7.0 & 8.5 & 6.76 & 7.36 & 7.06 & 0 & 19 \\
\hline Conductivity** & - & - & - & 1500 & 583 & 1596 & 923.93 & - & 4 \\
\hline TDS* & 500 & 2000 & 500 & 1500 & 337 & 937 & 555.7 & 14 & 14 \\
\hline Alkalinity* & 200 & 600 & - & - & 305 & 980 & 486.16 & 30 & - \\
\hline Total hardness* & 200 & 600 & 100 & 500 & 172 & 555 & 309.46 & 27 & 30 \\
\hline Calcium* & 75 & 200 & 75 & 200 & 39 & 96 & 62 & 4 & 4 \\
\hline Sodium* & - & - & - & 200 & 3.7 & 64 & 30.12 & - & - \\
\hline Magnesium* & 30 & 100 & 30 & 150 & 11.42 & 90.57 & 37.67 & 20 & 20 \\
\hline Potassium* & - & - & - & - & 1.6 & 4.6 & 2.82 & - & 0 \\
\hline Chloride* & 250 & 1000 & 200 & 600 & 26 & 129 & 59.9 & 0 & 0 \\
\hline Sulphate* & 200 & 400 & 200 & 400 & 11 & 59 & 26.97 & 0 & 0 \\
\hline Nitrate* & 45 & - & 45 & - & 21 & 34 & 29.03 & 0 & 0 \\
\hline Fluoride* & 1 & 1.5 & 1 & 1.5 & 0.36 & 0.58 & 0.45 & 0 & 0 \\
\hline
\end{tabular}

${ }^{*}$ In $\mathrm{mg} / \mathrm{L},{ }^{* *}$ in $\mu \mathrm{S} / \mathrm{cm}$ 
Fig. 2 Spatial distribution maps of different water quality constituents, i.e. a TDS, b alkalinity, $\mathbf{c}$ hardness, $\mathbf{d}$ calcium and e magnesium
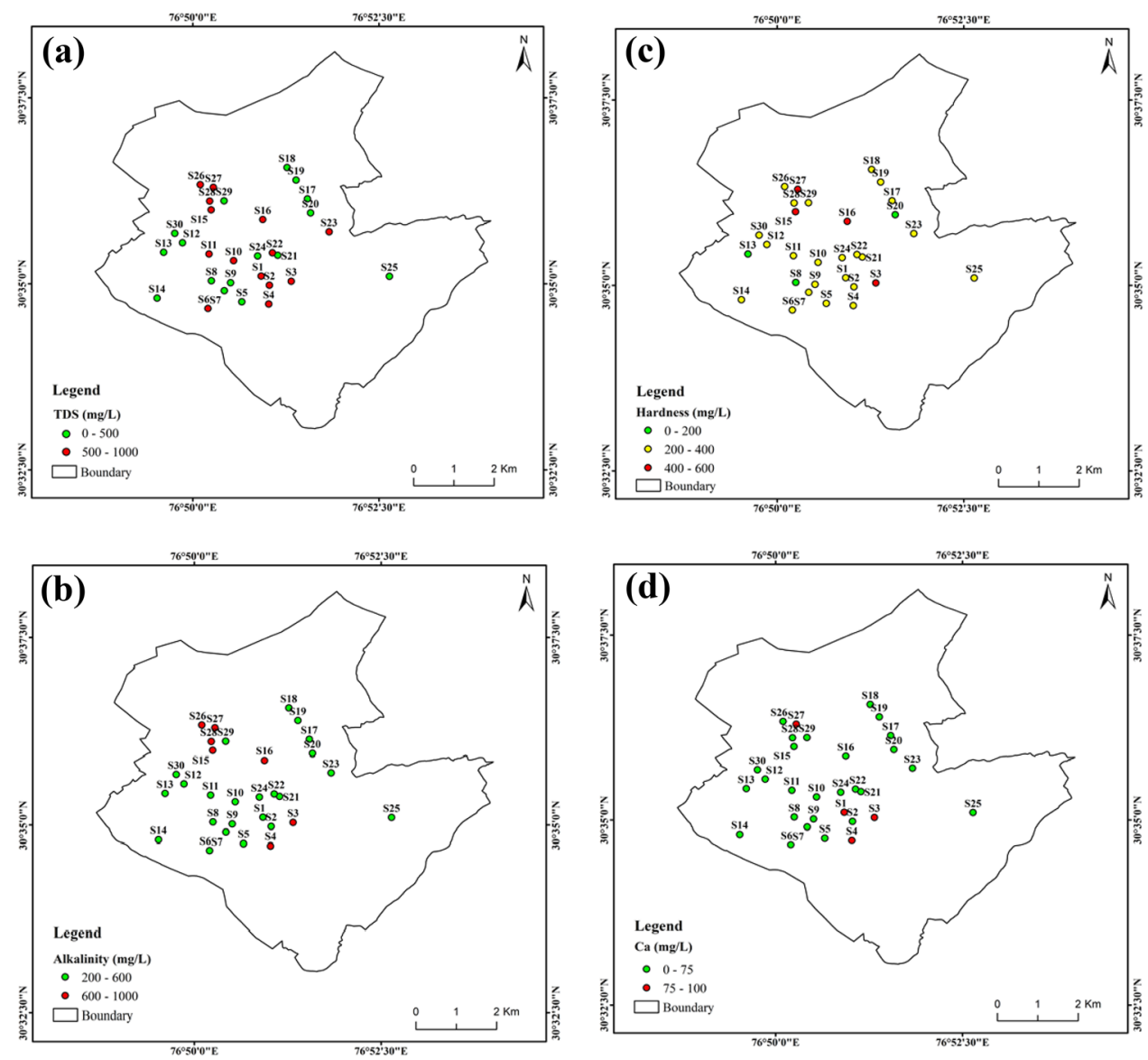

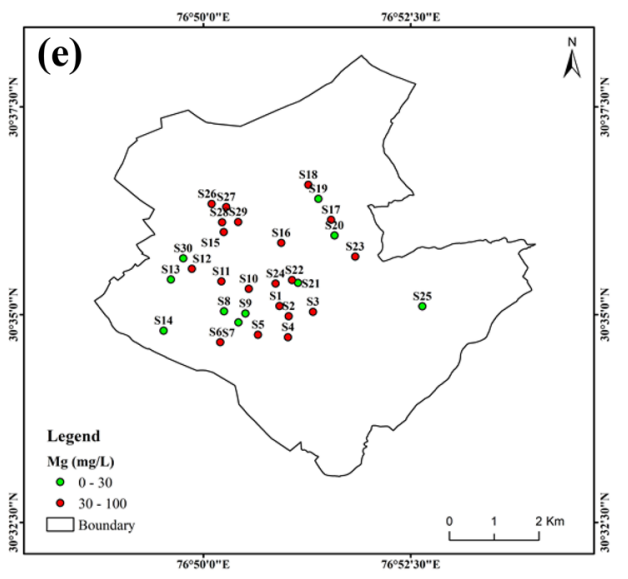

present in the soil gets dissolved in the groundwater. Alkalinity of water samples taken from the region was found to be varied from 305 to $980 \mathrm{mg} / \mathrm{L}$. Figure $2 \mathrm{~b}$ specifies that that groundwater alkalinity was more than desirable limit of $200 \mathrm{mg} / \mathrm{L}$ for all the samples [36]. Out of total 30 samples, 23 samples were falling between desirable and permissible limits and rest of the 7 samples ( $\mathrm{S} 1$, $\mathrm{S} 2, \mathrm{~S} 13, \mathrm{~S} 15, \mathrm{~S} 26, \mathrm{~S} 27$, and S28) were falling above permissible limit of $600 \mathrm{mg} / \mathrm{L}$. The minimum concentration of sodium was $3.4 \mathrm{mg} / \mathrm{L}$, and maximum concentration was $64 \mathrm{mg} / \mathrm{L}$ in the collected samples.

The concentration of total hardness found in the region varies from 172 to $555 \mathrm{mg} / \mathrm{L}$. The values of total hardness for only 3 samples (S8, S13, and S20) were below desirable limit while values for 27 samples were between desirable and permissible range. However, $96 \%$ of the groundwater samples fall in the category of very hard water (Fig. 2c). 
As per the obtained results for the concentration of various cations and anions under consideration, the order of the mean concentration for cation is $\mathrm{Ca}^{2+}>\mathrm{Mg}^{2+}>\mathrm{Na}^{+}>\mathrm{K}^{+}$ while the order of the mean concentration for anions is $\mathrm{Cl}^{-}>\mathrm{NO}_{3}{ }^{-}>\mathrm{SO}_{4}{ }^{2-}>\mathrm{F}^{-}$. The concentrations of $\mathrm{Ca}^{2+}$ and $\mathrm{Mg}^{2+}$ ions varied from 39 to $96 \mathrm{mg} / \mathrm{L}$ and 11.42 to $90.57 \mathrm{mg} / \mathrm{L}$, respectively. Twenty-six groundwater samples were having calcium ion concentration below maximum desirable limit and only four groundwater samples ( $\mathrm{S} 1$, S2, S27, and S30) were found to have calcium ion concentration more than the maximum desirable limit (Fig. 2d). On the other hand, magnesium ion concentration for 10 samples was below the desirable limit; however, rest of the 20 groundwater samples (S1, S2, S3, S4, S8, S9, S10, S13, S15, S16, S17, S20, S22, S23, S24, S26, S27, S28, S29 and S30) were having magnesium ion concentration above the maximum desirable limit (Fig. 2e).
It was observed that the potassium concentrations were within the permissible limits, i.e. $10 \mathrm{mg} / \mathrm{L}$ as given by European Economic Community for all the water samples. The potassium concentration varied from 1.6 to $4.6 \mathrm{mg} / \mathrm{L}$. Sodium and potassium are not considered as a drinking water parameter in BIS 2012 standards [36], while it was found that the concentrations of sulphate, nitrate, chloride and fluoride for all the collected water samples have reported below the desirable limit.

\subsection{Water quality classification for irrigation}

There are different irrigation parameters mentioned in Table 3 on the basis of which classification of the water samples of the study area is done. TDS concentration for all the groundwater samples was found to be less than $1000 \mathrm{mg} / \mathrm{L}$; thus, these samples can be classified as fresh

Table 3 Categorization of Groundwater samples for Irrigation Purpose

\begin{tabular}{|c|c|c|c|c|}
\hline Physicochemical parameters & Range & $\begin{array}{l}\text { Number of samples within } \\
\text { the specified range }\end{array}$ & Category & References \\
\hline \multirow[t]{4}{*}{ Total dissolved solid (TDS) (mg/L) } & $<1000$ & 30 & Fresh & {$[38]$} \\
\hline & $1000-10,000$ & 0 & Brackish & \\
\hline & $10,000-100,000$ & 0 & Saline & \\
\hline & $>100,000$ & 0 & Brine & \\
\hline \multirow[t]{5}{*}{ Salinity hazard (EC) ( $\mu \mathrm{S} / \mathrm{cm})$} & $<250$ & 0 & Excellent & {$[27]$} \\
\hline & $250-750$ & 11 & Good & \\
\hline & $750-2000$ & 19 & Permissible & \\
\hline & $2000-3000$ & 0 & Doubtful & \\
\hline & $>3000$ & 0 & Unsuitable & \\
\hline \multirow[t]{4}{*}{ Alkalinity hazard (SAR) } & $<10$ & 30 & Excellent & {$[25]$} \\
\hline & $10-18$ & 0 & Good & \\
\hline & $18-26$ & 0 & Doubtful & \\
\hline & $>26$ & 0 & Unsuitable & \\
\hline \multirow[t]{5}{*}{ Percent sodium (\%Na) } & $<20$ & 17 & Excellent & {$[27]$} \\
\hline & $20-40$ & 11 & Good & \\
\hline & $40-60$ & 2 & Permissible & \\
\hline & $60-80$ & 0 & Doubtful & \\
\hline & $>80$ & 0 & Unsuitable & \\
\hline \multirow[t]{2}{*}{ Kelly's ratio (KR) } & $<1$ & 30 & Suitable & {$[28]$} \\
\hline & $>1$ & 0 & Unsuitable & \\
\hline \multirow[t]{2}{*}{ Magnesium ratio (MR) } & $>50 \%$ & 16 & Suitable & [29] \\
\hline & $<50 \%$ & 14 & Unsuitable & \\
\hline \multirow[t]{3}{*}{ Residual sodium carbonate (RSC) } & $<1.25$ & 6 & Suitable & {$[34]$} \\
\hline & $1.25-2.5$ & 11 & Marginally suitable & \\
\hline & $>2.5$ & 13 & Unsuitable & \\
\hline \multirow[t]{2}{*}{ Corrosivity ratio $(\mathrm{CR})$} & $<1$ & 30 & Suitable & {$[32]$} \\
\hline & $>1$ & 0 & Unsuitable & \\
\hline \multirow[t]{3}{*}{$\mathrm{PI}(\mathrm{meq} / \mathrm{L})$} & Class 1 & 90 & Max. permeability & {$[35]$} \\
\hline & Class 2 & 10 & $75 \%$ of max. permeability & \\
\hline & Class 3 & 0 & $25 \%$ of max. permeability & \\
\hline
\end{tabular}


water or non-saline. Also, it is mentioned that high EC in water can make the soil saline. Thus, EC value plays critical role in determining the fitness of water for irrigation purposes. As per EC value of the groundwater samples of the area under study, about $36.33 \%$ of the samples were classified as good category and rest of the all samples fall under permissible category. The values of SAR in the samples varied from 0.08 to 1.99 . All the groundwater samples have shown SAR $<10$ and considered as excellent for irrigation (Table 3). Further, by plotting obtained values of SAR (sodium hazard) and EC (salinity hazard) on the US Salinity Laboratory (USSL) diagram, the class/type of irrigational water can also be determined. From the plot (Fig. 3), it is evident that groundwater of only $36.77 \%$ falls under water type C2-S1 (medium salinity-low SAR), such water can be used to irrigate soil with moderate leaching and only for those plants which are moderately salt tolerant and can grow without adopting any special practices for salinity control. At rest of the $64.33 \%$ sites, groundwater belongs to category C3-S1 (high salinity-low SAR). Hence, the water of these sites cannot be used as irrigation water for the soils with limited drainage. However, in order to use the water of these site even for the soils with adequate drainage, special management practices for salinity control need to be implemented and only plants with high salt tolerance could be selected.
Sodium percent values varied from 3.08 to $45.86 \%$, indicating that all groundwater samples were below permissible value. Further according to the Kelly's ratio, the collected groundwater samples were fit for irrigation purpose as they fall below 1 (Table 3). Magnesium ratio was calculated for the collected samples and observed that only $53.33 \%$ groundwater samples were fit for the irrigation use (Table 3). Samples S1, S2, S5, S6, S7, S11, S14, S18, S19, $\mathrm{S} 21, \mathrm{~S} 26, \mathrm{~S} 27, \mathrm{~S} 28$, and $\mathrm{S} 30$ has magnesium ratio less than $50 \%$. So, these samples are considered as unsuitable for the irrigation purpose according to the magnesium ratio.

Lloyd and Heathcote [34] had introduced an equation to calculate the residual sodium carbonate (RSC). Only $20 \%$ samples fall under suitable category with $\mathrm{RSC}<1.25$, $36.66 \%$ samples can thus be considered in marginally suitable category with RSC value from 1.25 to 2.5 , however, 43.33\% fall in the unsuitable category with RSC $>2.5$ ( $\mathrm{S} 1$, $\mathrm{S} 2, \mathrm{~S} 5, \mathrm{~S} 6, \mathrm{~S} 8, \mathrm{~S} 13, \mathrm{~S} 15, \mathrm{~S} 18, \mathrm{~S} 20, \mathrm{~S} 21, \mathrm{~S} 26, \mathrm{~S} 27, \mathrm{~S} 28$ are unsuitable for irrigation according to the RSC). The corrosivity ratio $(C R)$ for all samples was less than 1 which indicated that groundwater can be transported through the pipes.

In the present study, permeability index ranges from 43.42 to 80.07 . As per Doneen [35] classification of water on the basis of PI values, $90 \%$ of samples from the study area come under class I category signifying that water is
Fig. 3 US Salinity Laboratory (USSL) diagram
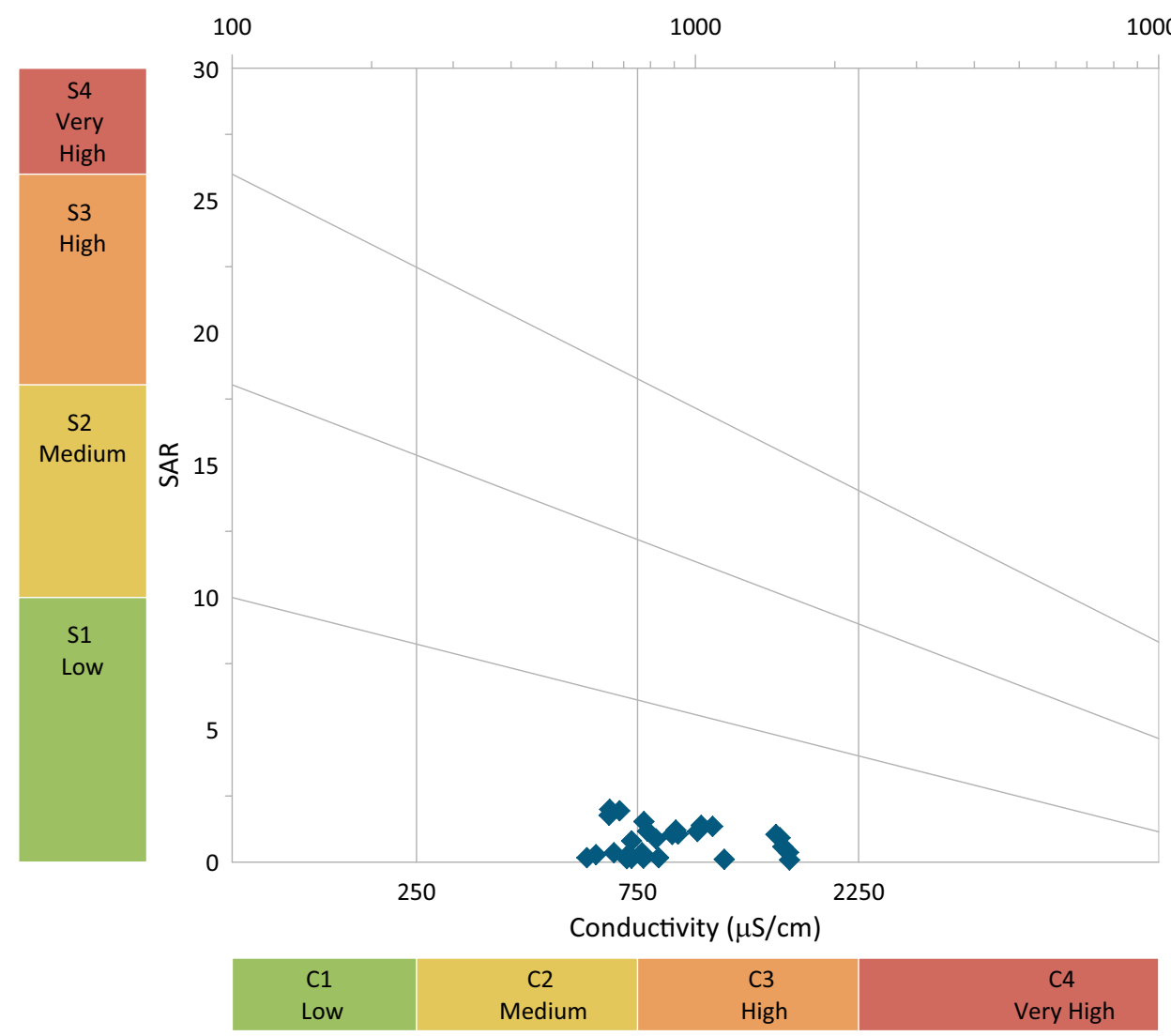
good for irrigation uses at majority of sites. Even also in the rest of the sites, groundwater lies in class II and is marginally fit for irrigation.

\subsection{Mechanism controlling groundwater chemistry}

The Pearson correlation matrix (Table 4) is used to recognize the relationship between different variables. Value of correlation coefficient less than 0.5 is considered weak correlation, $0.5-0.75$ as moderate correlation and more than 0.75 as strong correlation. Significant positive correlation was noticed between EC-TDS $(r=0.99)$, EC-TA $(r=0.98)$, $\mathrm{EC}-\mathrm{TH}(r=0.84), \mathrm{EC}-C a^{2+}(r=0.76), \mathrm{EC}-\mathrm{Mg}^{2+}(r=0.71)$, $\mathrm{EC}-S O_{4}{ }^{-}(r=0.92)$, TDS-TA $(r=0.97)$, TDS-TH $(r=0.82)$, TDS$\mathrm{Ca}^{2+}(r=0.79), \mathrm{TDS}^{-\mathrm{Mg}^{2+}}(r=0.68), \mathrm{TDS}^{2} \mathrm{SO}_{4}^{-}(r=0.89)$, $\mathrm{TA}^{-\mathrm{SO}_{4}{ }^{-}}(r=0.94), \mathrm{TA}-\mathrm{TH}(r=0.79), \mathrm{TA}^{-\mathrm{Ca}^{2+}}(r=0.76)$, $\mathrm{TA}^{-\mathrm{Mg}^{2+}}(r=0.64), \mathrm{TH}-\mathrm{Ca}^{2+}(r=0.72), \mathrm{TH}^{2} \mathrm{Mg}^{2+}(r=0.94)$, $\mathrm{TH}^{-\mathrm{SO}_{4}}{ }^{-}(r=0.77), \mathrm{TH}^{-} \mathrm{NO}_{3}{ }^{-}(r=0.67)$, which revealed that the presence of $\mathrm{TH}, \mathrm{TA}, \mathrm{Ca}^{2+}, \mathrm{Mg}^{2+}$ and $\mathrm{SO}_{4}{ }^{-}$was strongly correlated with EC and TDS.

Significant positive correlation between $\mathrm{EC}$ and $\mathrm{Mg}^{2+}$ $(r=0.71), \mathrm{K}^{+}(r=0.43), \mathrm{NO}_{3}{ }^{2-}(r=0.54)$ and $\mathrm{SO}_{4}{ }^{2-}(r=0.92)$ shows that these ions are contributing significantly to $\mathrm{EC}$ [26] and suggest that significant anthropogenic activities are responsible for the addition of these ions into the groundwater of the region [6]. Further, moderate correlation of $\mathrm{NO}_{3}{ }^{2-}$ and $\mathrm{Cl}^{-}(r=0.51)$ elucidates the presence of anthropogenic sources such as punctured sewer pipelines [6], whereas moderate positive correlations among $\mathrm{Ca}^{+}$and $\mathrm{NO}_{3}{ }^{2-}$ also reveal the impact of fertilizers in the groundwater [26]. The total hardness (TH) has strong correlations with $\mathrm{Mg}^{2+}(0.94), \mathrm{SO}_{4}{ }^{2-}(r=0.77)$, and a moderate correlation with $\mathrm{Ca}^{2+}(0.72), \mathrm{NO}_{3}{ }^{2-}(\mathrm{r}=0.67)$ indicates that hardness is mostly related to $\mathrm{Mg}^{2+}$ than $\mathrm{Ca}^{2+}[26]$ and is permanent hardness. Not only anthropogenic sources but natural sources of are also affecting the groundwater quality which is indicated from strong correlation of $\mathrm{SO}_{4}{ }^{2-}$ with $\mathrm{Ca}^{2+}(r=0.83)$ that point to the dissolution of gypsum mineral from the rock matrix as a reason of the addition of $\mathrm{SO}_{4}{ }^{2-}$ in groundwater of this region.

\subsubsection{Hydrogeochemical type of groundwater}

Chadha [39] had introduced a diagram to investigate various hydro-geochemical processes. The diagram has been plotted by changing values into percentage equivalents (meq\%). The $X$ axis is representing the difference between percentages of $\mathrm{Ca}^{2+}+\mathrm{Mg}^{2+}$ (alkaline earth metals) and $\mathrm{Na}^{+}+\mathrm{K}^{+}$(alkali metals) for cations and the $Y$ axis representing difference among $\mathrm{CO}_{3}{ }^{2-}+\mathrm{HCO}_{3}{ }^{-}$(weaker acidic anions) and $\mathrm{Cl}^{-}+\mathrm{SO}_{4}{ }^{2-}$ (stronger acidic anions) has shown in Fig. 4. Results obtained from the Chadha's plot have shown that most of the groundwater samples (27 samples) of study area belong to sub-field (6) which suggest that alkaline earth metals exceed alkali metals, whereas, strong acidic anions exceed weak acidic anions. These groundwater samples of study area belong to $\mathrm{Ca}^{2+}-\mathrm{Mg}^{2+}-\mathrm{Cl}^{-}$type, or $\mathrm{Ca}^{2+}-\mathrm{Mg}^{2+}$ dominant $\mathrm{Cl}^{-}$type, or $\mathrm{Cl}^{-}$dominant $\mathrm{Ca}^{2+}-\mathrm{Mg}^{2+}$ dominant type. However, groundwater samples of 3 sites belong to sub-field (8) which indicate that in groundwater sample of those areas, alkali metals exceed alkaline earth metals and weak acidic anions exceed strong acidic anions and the samples belong to $\mathrm{Na}^{+}-\mathrm{HCO}_{3}{ }^{-}$type, or $\mathrm{Na}^{+}$dominant $\mathrm{HCO}_{3}{ }^{-}$type, or $\mathrm{HCO}_{3}{ }^{-}$dominant $\mathrm{Na}^{+}$type [39]. Such

Table 4 Correlation matrix of various chemical parameters of groundwater samples of Dera Bassi

\begin{tabular}{|c|c|c|c|c|c|c|c|c|c|c|c|c|c|}
\hline & $\mathrm{pH}$ & EC & TDS & Alk & Hardness & $\mathrm{Na}^{+}$ & $\mathrm{K}^{+}$ & $\mathrm{Ca}^{2+}$ & $\mathrm{Mg}^{2+}$ & $\mathrm{Cl}^{-}$ & $\mathrm{SO}^{4-}$ & $\mathrm{NO}^{3-}$ & $\mathrm{F}^{-}$ \\
\hline $\mathrm{pH}$ & 1.00 & & & & & & & & & & & & \\
\hline EC & -0.11 & 1.00 & & & & & & & & & & & \\
\hline TDS & -0.09 & 0.99 & 1.00 & & & & & & & & & & \\
\hline Alk & -0.12 & 0.98 & 0.97 & 1.00 & & & & & & & & & \\
\hline Hardness & -0.15 & 0.84 & 0.82 & 0.79 & 1.00 & & & & & & & & \\
\hline $\mathrm{Na}^{+}$ & 0.21 & 0.08 & 0.09 & 0.04 & 0.08 & 1.00 & & & & & & & \\
\hline $\mathrm{K}^{+}$ & -0.31 & 0.43 & 0.47 & 0.38 & 0.58 & 0.26 & 1.00 & & & & & & \\
\hline $\mathrm{Ca}^{2+}$ & -0.24 & 0.76 & 0.79 & 0.76 & 0.72 & -0.14 & 0.58 & 1.00 & & & & & \\
\hline $\mathrm{Mg}^{2+}$ & -0.08 & 0.71 & 0.68 & 0.64 & 0.94 & 0.17 & 0.46 & 0.44 & 1.00 & & & & \\
\hline $\mathrm{Cl}^{-}$ & -0.03 & 0.08 & 0.11 & 0.01 & 0.19 & -0.53 & -0.13 & 0.17 & 0.17 & 1.00 & & & \\
\hline $\mathrm{SO}^{4-}$ & -0.13 & 0.92 & 0.89 & 0.94 & 0.77 & -0.04 & 0.36 & 0.83 & 0.59 & -0.05 & 1.00 & & \\
\hline $\mathrm{NO}^{3-}$ & -0.30 & 0.54 & 0.59 & 0.46 & 0.67 & -0.23 & 0.64 & 0.62 & 0.55 & 0.51 & 0.35 & 1.00 & \\
\hline $\mathrm{F}^{-}$ & -0.03 & 0.53 & 0.53 & 0.53 & 0.39 & -0.02 & 0.11 & 0.62 & 0.20 & -0.04 & 0.64 & 0.13 & 1.00 \\
\hline
\end{tabular}

*Significant at 0.05 level 


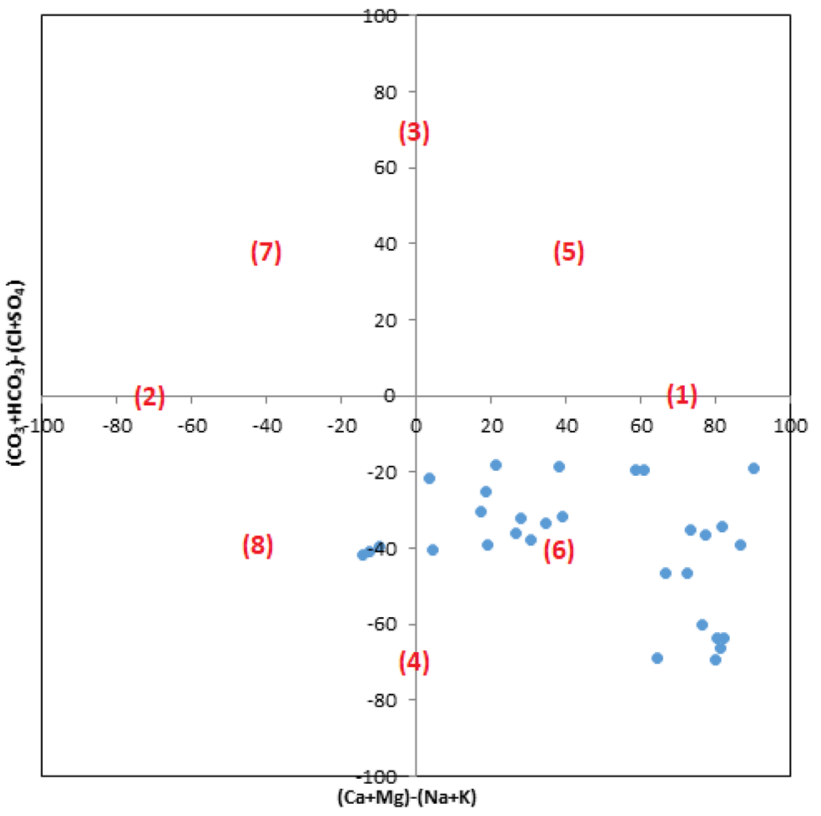

Fig. 4 Chadha's plot representing hydrochemical processes and percentage of various cations and anions present in groundwater samples

groundwater generates residual sodium carbonate during irrigation use and also cause foaming problems.

\subsubsection{Gibbs diagram and water-rock interaction}

In order to ascertain the suitability of ground water for both domestic and irrigation purposes, groundwater chemistry is a main conclusive factor [30] and the groundwater chemistry itself is usually governed by three natural mechanisms, i.e. evaporation rate, atmospheric precipitation and the water-rock interaction $[3,40]$. To explain the role of these three important natural mechanisms in controlling the major ion chemistry of the groundwater, Gibbs [41] introduced Gibbs scatter diagram. Gibbs ratio 1 (for anion) and Gibbs ratio 2 (for cation) were calculated in order to draw the scatter diagram using the equations given below:

Gibbs Ratio $1=\frac{\mathrm{Cl}^{-}}{\left(\mathrm{Cl}^{-}+\mathrm{HCO}_{3}^{-}\right)}$

Gibbs Ratio $2=\frac{\mathrm{Na}^{+}+\mathrm{K}^{+}}{\mathrm{Na}^{+}+\mathrm{K}^{+}+\mathrm{Ca}^{2+}}$

It is clear from Gibbs diagrams (Fig. 5a-b) that all the water samples fall in rock dominance category which indicate that chemical weathering of rock minerals is affecting the quality of groundwater $[1,4]$.
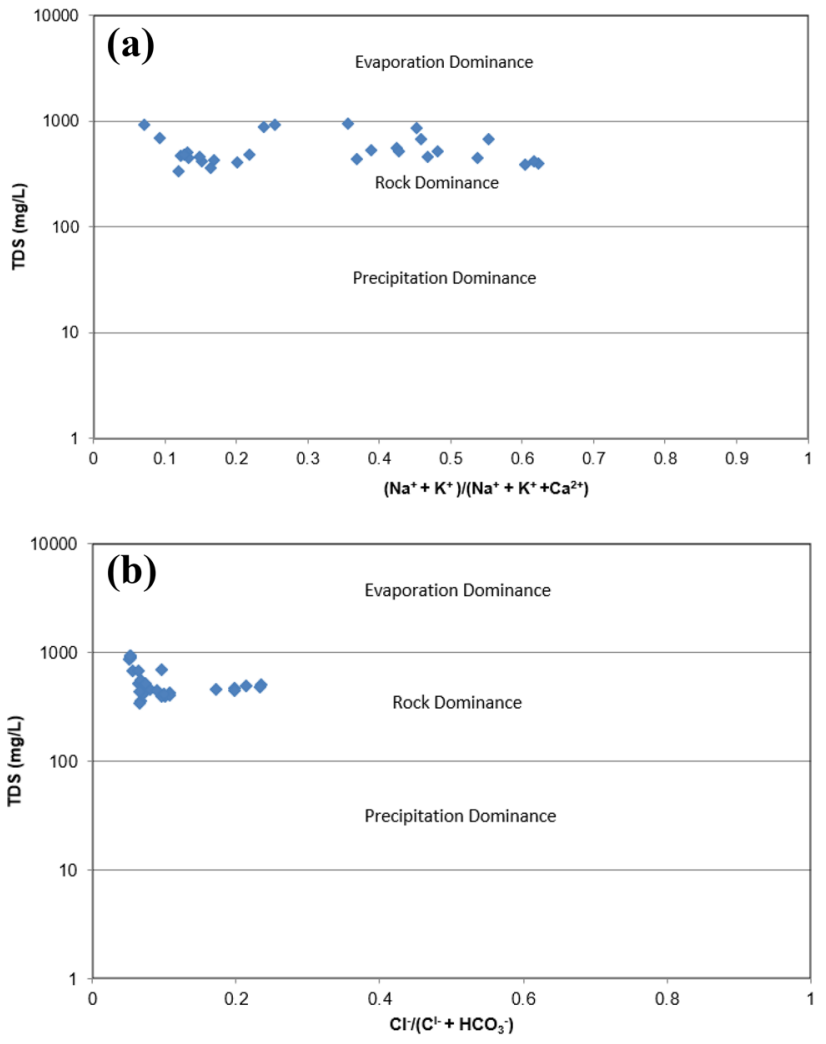

Fig. 5 Gibbs diagram for a Gibbs ratio (cations); b Gibbs ratio (anions)

Plot between $\mathrm{Ca}+\mathrm{Mg}(\mathrm{meq} / \mathrm{L})$ and $\mathrm{HCO}_{3}+\mathrm{SO}_{4}$ (meq/L) expresses information regarding the weathering and dissolution of minerals. This plot can also provide information about the main minerals contributive to groundwater mineralization [42]. It is clearly evident from the scatter diagram of $\mathrm{Ca}+\mathrm{Mg}(\mathrm{meq} / \mathrm{L})$ and $\mathrm{HCO}_{3}+\mathrm{SO}_{4}(\mathrm{meq} / \mathrm{L})$ (Fig. 6) that the silicate weathering was the primary process involved in the evolution of groundwater as majority of samples (approx. 73\%) fall below the equiline [43].

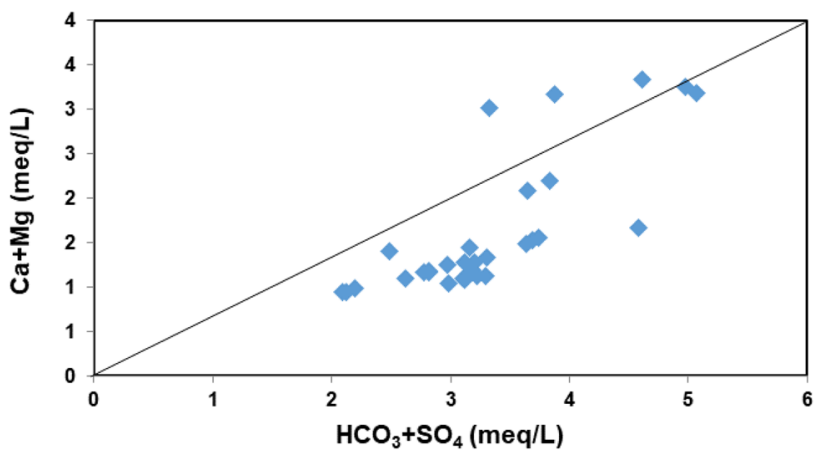

Fig. 6 Plot representing $(\mathrm{Ca}+\mathrm{Mg})$ versus $\left(\mathrm{HCO}_{3}+\mathrm{SO}_{4}\right)$ 


\subsubsection{Index of base exchange}

The chemical characteristics of groundwater get changed because of the ion exchange during percolation [44]. To know ion exchange taking place in the groundwater and its host environment, the Chloro-alkaline indices (CAI 1 and $\mathrm{CAI} 2$ ) are evaluated by applying the following equations [45].

Chloro - alkaline index $1=\frac{\mathrm{Cl}-(\mathrm{Na}+\mathrm{K})}{\mathrm{Cl}}$

Chloro - alkaline index $2=\frac{\mathrm{Cl}-(\mathrm{Na}+\mathrm{K})}{\mathrm{SO}_{4}+\mathrm{HCO}_{3}+\mathrm{CO}_{3}+\mathrm{NO}_{3}}$

According to Schollar [45], the CAI values will be negative if $\mathrm{Ca}$ and $\mathrm{Mg}$ of groundwater get exchanged with $\mathrm{Na}$ and $\mathrm{K}$ of aquifer material which represents the direct ion exchange. However, if $\mathrm{Na}$ and $\mathrm{K}$ present in groundwater get exchanged with $\mathrm{Ca}$ and $\mathrm{Mg}$ present in the aquifer material, then CAl values will be positive that will indicate the reverse ion exchange process. If CAl value comes out to be zero, it means no ion exchange process is favoured. In the present study, CAI 1 and CAI 2 values ranged from -1.35 to 0.90 and -1.16 to 1.78 , respectively. The values of CAI 1 and CAI 2 were negative for $50 \%$ samples under investigation which represents that both normal ion exchange and reverse ion exchange processes prevail (Fig. 7).

\section{Conclusion}

The groundwater analysis for the Dera Bassi town and its surrounding agricultural area was carried out to assess its suitability for drinking and irrigation purposes. From the results obtained by physico-chemical analysis of the groundwater samples, it is clear that all of the water samples were below the acceptable limit of BIS (2012) and WHO (2006) for $\mathrm{pH}, \mathrm{F}^{-}, \mathrm{Cl}^{-}, \mathrm{NO}_{3}{ }^{-}$, and $\mathrm{SO}_{4}{ }^{2-}$. However, samples exceeded the acceptable limit in case of TDS, $\mathrm{TH}$, Alkalinity, $\mathrm{Ca}^{2+}$ and $\mathrm{Mg}^{2+}$ but found to be with in the maximum permissible limit except alkalinity whose value fall above the permissible limit at few sites. However, as per TH classification, $96 \%$ of the sampling sites fall in the category of very hard water category. Concentration of the anions for all the water samples were below the acceptable limit. The pattern of ionic dominance was observed as $\mathrm{Ca}^{2+}>\mathrm{Mg}^{2+}>\mathrm{Na}^{+}>\mathrm{K}^{+}$for cations and $\mathrm{Cl}^{-}>\mathrm{NO}_{3}{ }^{-}>\mathrm{SO}_{4}{ }^{2-}>\mathrm{F}^{-}$for anions. Hydrochemical studies revealed that majority of groundwater samples of study area belong to $\mathrm{Ca}^{2+}-\mathrm{Mg}^{2+}-\mathrm{Cl}^{-}$type, or $\mathrm{Ca}^{2+}-\mathrm{Mg}^{2+}$ dominant $\mathrm{Cl}^{-}$type, or $\mathrm{Cl}^{-}$dominant $\mathrm{Ca}^{2+}-\mathrm{Mg}^{2+}$ dominant type. type. Further, from the Gibbs diagrams it can be clear that all the water samples fall in rock dominance category which indicate that the quality of groundwater is being affected by chemical weathering of rock minerals. It is further evident from the plot between $\mathrm{Ca}+\mathrm{Mg}(\mathrm{meq} / \mathrm{L})$ and $\mathrm{HCO}_{3}+\mathrm{SO}_{4}$ (meq/L) that the silicate weathering is the primary process involved in the evolution of groundwater as majority of samples (approx. 73\%) fall below the equiline. Index to base exchange values indicates that both direct ion and reverse ion exchange processes were taking place in the region.
Fig. 7 Chloro-alkaline indices for groundwater samples of Dera Bassi

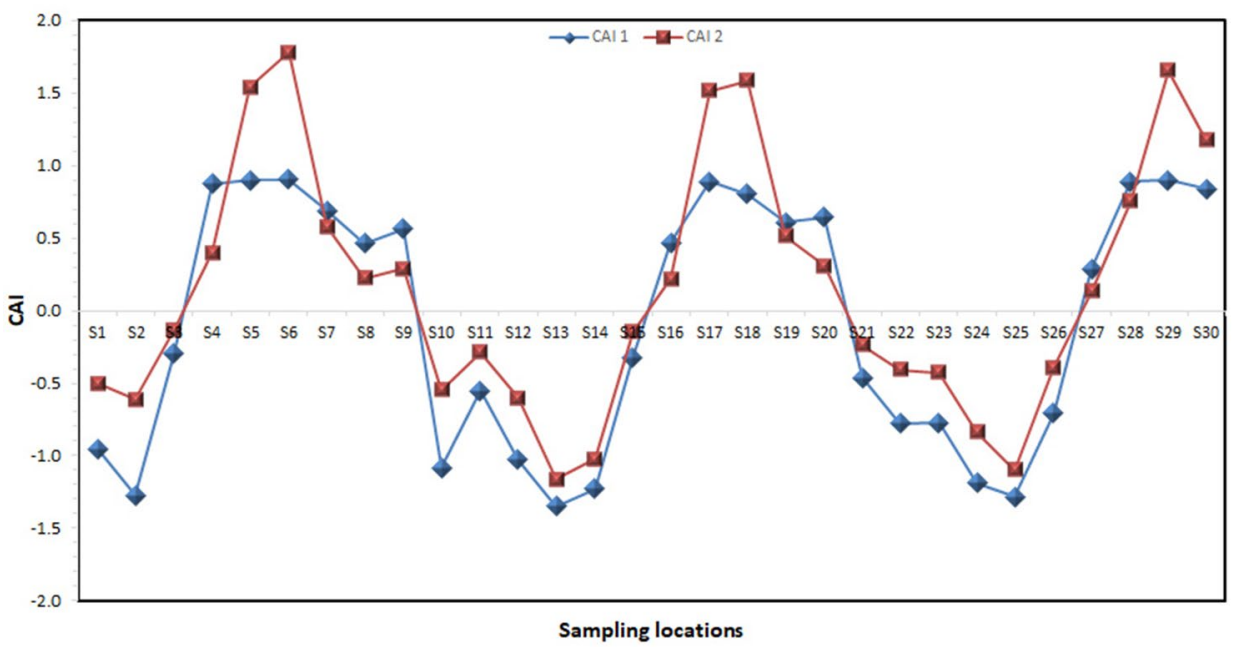


Sodium adsorption ratio (SAR), sodium percent ( $\mathrm{Na} \%)$ and Kelly's ratio (KR) indicated that most of groundwater samples were safe for the irrigation use. However, magnesium ratio indicated that the only $53.33 \%$ groundwater sampling sites were suitable for irrigation use. Further, results of residual sodium carbonate (RSC) revealed that $20 \%$ groundwater samples from the study area were fit for irrigation, $36.66 \%$ were marginally fit for the irrigation use while $43.33 \%$ of samples (S1, S2, S5, S6, S8, S13, S15, S18, S20, S21, S26, S27, S28) fall under unsuitable category with RSC $>2.5$. Further, based on PI values, $90 \%$ of samples come under class I category signifying that water is good for irrigation purpose at majority of sites of the study area; however, in the rest of the sites also it is marginally fit for irrigation purpose. Also, the $C R$ results for all the water samples recommend that groundwater can be transported through pipes.

\section{Compliance with ethical standards}

Conflict of interest The authors declare that they have no conflicts of interest.

Open Access This article is licensed under a Creative Commons Attribution 4.0 International License, which permits use, sharing, adaptation, distribution and reproduction in any medium or format, as long as you give appropriate credit to the original author(s) and the source, provide a link to the Creative Commons licence, and indicate if changes were made. The images or other third party material in this article are included in the article's Creative Commons licence, unless indicated otherwise in a credit line to the material. If material is not included in the article's Creative Commons licence and your intended use is not permitted by statutory regulation or exceeds the permitted use, you will need to obtain permission directly from the copyright holder. To view a copy of this licence, visit http://creativecommons .org/licenses/by/4.0/.

\section{References}

1. Adimalla N (2019) Groundwater quality for drinking and irrigation purposes and potential health risks assessment: a case study from semi-arid region of South India. Expos Health 11:109-123. https://doi.org/10.1007/s12403-018-0288-8

2. Adimalla N, Qian H, Nandan MJ (2020) Groundwater chemistry integrating the pollution index of groundwater and evaluation of potential human health risk: a case study from hard rock terrain of south India. Ecotoxicol Environ Saf 206:111217. https://doi.org/10.1016/j.ecoenv.2020.111217

3. Jain CK, Vaid U (2018) Assessment of groundwater quality for drinking and irrigation purposes using hydrochemical studies in Nalbari district of Assam, India. Environ Earth Sci 77:254. https://doi.org/10.1007/s12665-018-7422-6

4. Adimalla N, Li P (2019) Occurrence, health risks, and geochemical mechanisms of fluoride and nitrate in groundwater of the rock-dominant semi-arid region, Telangana State, India. Hum
Ecol Risk Assess 25:81-103. https://doi.org/10.1080/10807 039.2018.1480353

5. Adimalla N, Qian H (2021) Groundwater chemistry, distribution and potential health risk appraisal of nitrate enriched groundwater: a case study from the semi-urban region of South India. Ecotoxicol Environ Saf 207:111277. https://doi. org/10.1016/j.ecoenv.2020.111277

6. Ahamad A, Madhav S, Singh P, Pandey J, Khan AH (2018) Assessment of groundwater quality with special emphasis on nitrate contamination in parts of Varanasi City, Uttar Pradesh, India. Appl Water Sci 8:115. https://doi.org/10.1007/s1320 1-018-0759-x

7. Kumar R, Vaid U, Mittal S (2018) Water crisis: issues and challenges in Punjab. In: Singh V, Yadav S, Yadava R (eds) Water resources management. Water science and technology library, vol 78. Springer, Singapore. https://doi. org/10.1007/978-981-10-5711-3_7

8. Sharma P, Sarma HP, Mahanta C (2012) Evaluation of groundwater quality with emphasis on fluoride concentration in Nalbari District, Assam, Northeast India. Environ Earth Sci 65:2147-2159. https://doi.org/10.1007/s12665-011-1195-5

9. Hindustan times (2017) Not just scarcity, groundwater contamination is India's hidden crisis. https://bit.ly/37TLOBp. Accessed 11 Jan 2020

10. Raina S, Dua K, Singh S (2019) Effect of drinking water having high F livestock health in Mansa and Bathinda districts of Punjab, India. Int J Curr Microbiol Appl Sci 8:548-555. https:// doi.org/10.20546/ijcmas.2019.808.065

11. Chanda IK (2013) Fertilizer consumption: sate wise pattern. https ://geographyandyou.com/fertiliser-consumption-state-wisepattern/. Accessed 7 Mar 2020

12. Ahada CPS, Suthar S (2018) Groundwater nitrate contamination and associated human health risk assessment in southern districts of Punjab, India. Environ Sci Pollut Res 25:25336-25347. https://doi.org/10.1007/s11356-018-2581-2

13. Dev R, Bali M (2018) Evaluation of groundwater quality and its suitability for drinking and agricultural use in district Kangra of Himachal Pradesh, India. J Saudi Soc Agric Sci 18:462-468. https ://doi.org/10.1016/j.jssas.2018.03.002

14. Agarwal A, Prajapati R, Singh OP, Raza SK, Thakur LK (2015) Pesticide residue in water-a challenging task in India. Environ Monit Assess 187:54. https://doi.org/10.1007/s10661-015-4287-y

15. Khajuria $A$ (2016) Impact of nitrate consumption: case study of Punjab, India. JWARP 8:211-216

16. Ahamad A, Raju NJ, Madhav S, Gossel W, Wycisk P (2019) Impact of non-engineered Bhalswa landfill on groundwater from quaternary alluvium in Yamuna flood plain and potential human health risk, New Delhi, India. Quat Int 507:352-369. https://doi. org/10.1016/j.quaint.2018.06.011

17. Chen J, Wu H, Qian H (2016) Groundwater nitrate contamination and associated health risk for the rural communities in an agricultural area of Ningxia, Northwest China. Expo Health 8:349-359. https://doi.org/10.1007/s12403-016-0208-8

18. Kaur G, Kumar R, Sahoo MS, PK, Vaid U, (2019) Ground/drinking water contaminants and cancer incidence: a case study of rural areas of South West Punjab. Hum Ecol Risk Assess Int J, India. https://doi.org/10.1080/10807039.2019.1705145

19. Li H, Son JH, Carlson KH (2016) Concurrence of aqueous and gas phase contamination of groundwater in the Wattenberg oil and gas field of northern Colorado. Water Res 88:458-466. https:// doi.org/10.1016/j.watres.2015.10.031

20. Niu B, Loáiciga HA, Wang Z, Zhan FB, Hong S (2014) Twenty years of global groundwater research: a science citation index expanded based bibliometric survey (1993-2012). J Hydrol 519:966-975. https://doi.org/10.1016/j.jhydrol.2014.07.064 
21. Ntengwe FW (2006) Pollutant loads and water quality in stream of heavily populated and industrialized towns. Phys Chem Earth 31:832-839. https://doi.org/10.1016/j.pce.2006.08.025

22. The Indian Express, Chandigarh (2013). https://bit.ly/37mYmRm. Accessed 15 Sept 2019

23. Hindustan times, Mohali (2018) National Green Tribunal orders shut down of 57 factories in Dera Bassi. https://bit.ly/3fivQTQ. Accessed 16 Sept 2019

24. APHA (2017) Standard methods for the examination of water and wastewater, 23rd edn. American Public Health Association, Washington

25. Richards LA (1954) Diagnosis and improvement of saline and alkali soils. Agricultural handbook no. 60. United States Department of Agriculture, Washington

26. Keesari T, Ramakumar KL, Chidambaram S, Pethperumal S, Thilagavathi R (2016) Understanding the hydrochemical behavior of groundwater and its suitability for drinking and agricultural purposes in Pondicherry. South India-a step towards sustainable development. Groundw Sustain Dev 2:143-153. https:// doi.org/10.1016/j.gsd.2016.08.001

27. Wilcox LV (1955) Classification and use of irrigation waters. United States Department of Agriculture, Washington

28. Kelley WP, Brown SM, Liebig GF (1940) Chemical effects of saline irrigation water on soils. Soil Sci 49:95-108

29. Szabolcs I, Darab C (1964) The influence of irrigation water of high sodium carbonate content of soils. In: Proceedings of 8th international congress of ISSS, transmission, vol 2, pp 803-812

30. Kaur T, Bhardwaj R, Arora S (2017) Assessment of groundwater quality for drinking and irrigation purposes using hydrochemical studies in Malwa region, southwestern part of Punjab. Appl Water Sci 7:3301-3316. https://doi.org/10.1007/s1320 1-016-0476-2

31. Kumar M, Kumari K, Ramanathan AL, Saxena R (2007) A comparative evaluation of groundwater suitability for irrigation and drinking purposes in two intensively cultivated districts of Punjab, India. Environ Geol 53:553-574. https://doi.org/10.1007/ s00254-007-0672-3

32. Ryner JW (1944) A new index for determining amount of calcium carbonate scale formed by water. J Am Water Assoc 36:472-486

33. Eaton EM (1950) Significance of carbonates in irrigation waters. Soil Sci 69:123-133

34. Lloyd JW, Heathcote JA (1985) Natural inorganic hydrochemistry in relation to groundwater. Clarendon, Oxford, p 294

35. Doneen LD (1964) Notes on water quality in agriculture, published as a water science and engineering paper 4001.
Department of Water Sciences and Engineering, University of California, Berkeley

36. BIS (2012) Specifications for drinking water, IS: 10500:2012. Bureau of Indian Standards, New Delhi

37. WHO (2006) Guidelines for drinking-water quality: first addendum to third edition. Recommendations, vol 1. World Health Organization (WHO), Geneva, p 515

38. Freeze RA, Cherry JA (1979) Groundwater. Prentice-Hall, Englewood Cliffs, $p 604$

39. Chadha DK (1999) A proposed new diagram for geochemical classification of natural waters and interpretation of chemical data. Hydrogeol J 7:431-439. https://doi.org/10.1007/s1004 00050216

40. Subramani T, Rajmohan N, Elango L (2010) Groundwater geochemistry and identification of hydrogeochemical processes in a hard rock region, Southern India. Environ Monit Assess 162:123-137. https://doi.org/10.1007/s10661-009-0781-4

41. Gibbs RJ (1970) Mechanism controlling water world chemistry. Science 170:1088-1090

42. Houatmia F, Azouzi R, Charef A, Bédir M (2016) Assessment of groundwater quality for irrigation and drinking purposes and identification of hydrogeochemical mechanisms evolution in Northeastern, Tunisia. Environ Earth Sci 75:746. https://doi. org/10.1007/s12665-016-5441-8

43. Tamma RG, Srinivasa RY, Mahesh J, Surinaidu L, Dhakate R, Gurunadha RVVS, Durga PM (2015) Hydrochemical assessment of groundwater in alluvial aquifer region, Jalandhar District, Punjab, India. Environ Earth Sci 73:8145-8153. https://doi. org/10.1007/s12665-014-3973-3

44. Aghazadeh N, Mogaddam AA (2010) Assessment of groundwater quality and its suitability for drinking and agricultural uses in the Oshnavieh area, Northwest of Iran. J Environ Prot 1:30-40. https://doi.org/10.4236/jep.2010.11005

45. Schoeller H (1967) Geochemistry of groundwater. An international guide for research and practice, chapter 15. UNESCO, Paris, pp 1-18

Publisher's Note Springer Nature remains neutral with regard to jurisdictional claims in published maps and institutional affiliations. 